\title{
AMBITION SELF-EVALUATION OF PRESCHOOL TEACHERS
}

Oksana V. Barsukova, Southern Federal University, Rostov-on-Don, Russia

\section{knesinka@mail.ru}

ABSTRACT: The article presents the results of the pilot study of ambition self-evaluation of preschool teachers. The pilot study of ambition selfevaluation of preschool teachers was conducted by the original questionnaire "Ambition self-evaluation." The study involved 48 preschool teacher aged 37-55 with 11-32 years of work experience. The study of ambition self-evaluation and its degrees showed that the preschool teachers consider themselves ambitious, or rather ambitious people, less than a fifth of the preschool teachers do not consider themselves to be rather unambitious, none of the preschool teachers considers himself an unambitious person and part of the preschool teachers, a little more than $10 \%$, found it difficult to answer this question. The preschool teachers have determined their degrees of ambition as following: a high degree of ambition was noted by $45.1 \%$ of preschool teachers, medium $31 \%$, low - 23.9\%.

The preschool teachers who consider themselves ambitious, note the medium and high degrees of ambition. The preschool teachers who consider themselves rather ambitious, note low, medium and high degrees (mainly high and medium). The preschool teachers who consider themselves rather unambitious, noted the low and medium degrees of ambition. All preschool teachers who do not consider themselves ambitious, considered themselves as people with low degree of ambition or absolutely unambitious. The preschool teachers who found it difficult to evaluate themselves, note the medium degree of ambition.

Thus, the majority of the preschool teachers consider themselves ambitious people and evaluate their ambition as medium (moderate) or high.

KEY WORDS: pilot study, preschool teachers, ambition, ambitious personality, unambitious personality, self-evaluation

Ambition - a "new" phenomenon in the psychological studies. At this point, the definition of ambition as presented in the psychology allows to refer it to the motivational mental formations, but the issues of its epistemology and ontology are left open. We understand ambition as the desire of man to become a significant person for others for real actions and achievements (Barsukova, 2010). In this regard, the study of the social image and self-evaluation of the ambition of people of different gender, age and ethnicity, different professions representatives seems to be relevant. In this case it seems relevant and interesting to study the ambition self-evaluation of the preschool teachers, as the present social situation places new demands to a human personality in general and to a professional's personality in particular. It is a society's demand for the new qualities of the personality. And one of these qualities is precisely the ambition as it is necessary for the social and professional achievements of the personality. The focus is on the performance and achievements of the personality that benefit both the personality and society.

Theoretical and methodological basis of the conducted psychological study was an integrative approach to the human psychology, developed in the tradition of the St. Petersburg school of psychology (Panferov, 2009).

In the pilot study of the images and self-evaluation of the ambition, we used the original questionnaire "Ambition" by O.V. Barsukova that includes the blocks with open and close-ended types of questions:

Block "Image of ambition" respondents give their definition of ambition, as well as choose one of the proposed options. Analysis of the results of this block of questions is of fundamental importance because, before continuing the further work on the completion of the questionnaire, respondents need to know the meaning of "ambition" to avoid ambiguity in the analysis and interpretation of the survey results.

Block "Ambition self-evaluation" respondents evaluate their own ambition (its presence/absence, degree). 
Block "Moral evaluation of ambition" - respondents evaluate ambition as a moral (ethical) category in terms of "good" and "bad", specify particular types of ambition in terms of morality.

Block "Social desirability of ambition" - ambition is evaluated in terms of the social and professional desirability and necessity of the manifestations of ambition, sex and age characteristics of ambition are specified.

Our pilot study involved 48 preschool teacher aged 37-55 with 11-32 years of work experience.

Pedagogical ambition is defined by the preschool teachers as a motivational (65.96\%), reflexive (14.89\%), moral (10.64\%) and affective (8.51\%) mental formation according to the concept of the mental structure by V.N. Panferov (Panferov, 2009).

The definition of ambition as a motivational formation (65.96\%) prevails. Pedagogical ambition is defined as the pursuit of the professional development, such as the need to obtain professional awards, as the desire to become famous. The following are the definitions of ambition as a reflexive, moral and affective mental formation: In defining the pedagogical ambition as a reflexive formation (14.89\%) stated that it is a manifestation of the selfesteem, self-respect, self-worth as a professional. In addition, the preschool teachers note such an important, in their view, reflexive characteristic of the ambitious teacher as image-building and self observation. Ambition as a moral formation $(10.64 \%)$ is characterized by the status that a person occupies in the staff, how he is treated (valued, respected, consulted) by the colleagues, superiors. Ambition as an affective formation (8.51\%) is in those emotions and feelings that a person experiences in a situation of achieving professional success and praise, receiving awards and celebration - enthusiasm, delight, desire to relive those emotions.
Goals that according to the responses of the preschool teachers are set by an ambitious person, can be represented in the form of five groups:

Respect. In this case, it is the desire to earn the respect of the colleagues, coworkers, etc. The key to understanding this desire is the word "to earn" such treatment.

Professionalism. This goal includes getting a higher education, a commitment to the continuous professional growth, improvement and further development.

Career. The main goal of the teacher in this case - to "make a career", hold high administrative positions - Head Master/Mistress, Educational supervisor, Chief, Minister. Preschool teachers in the description of this goal mentioned external, formal verification of a high status, such as a private office, assistants, etc.

Fame. This goal requires that a person will become famous thanks to the winning a professional competition, developing a methodology, writing textbook, etc. This goal can be considered as a "continuation" of the desire for the professional growth, but the emphasis here is on becoming famous, and then on the achievements that will bring this fame.

Image. Image, according to the preschool teachers, plays an important role in the social and professional success, at the achievement of which the ambitious aspirations are aimed. Preschool teachers note that they and their colleagues have attached great importance to their appearances. It can be argued that the preschool teachers tend to meet the standard of the visual appeal to endear children and their parents The preschool teachers included the following components in the image: appearance, style (professional style, manner of speaking, dress code) and work experience.

According to the results of the study of the ambition self-evaluation, we obtained the following results: 
- most preschool teachers consider themselves ambitious, or rather ambitious (28.2\% and $42.3 \%$, respectively);

- $18.1 \%$ of the preschool teachers consider themselves rather unambitious;

- none of the preschool teachers considers oneself an unambitious;

- part of the preschool teachers found it difficult to answer this question (11.4\%).

The preschool teachers have determined their degree of ambition as follows:

- a high level of ambition was noted by $45.1 \%$ of the preschool teachers;

$$
\begin{aligned}
& \text { - medium - 31\%; } \\
& \text { - low - 23.9\%. }
\end{aligned}
$$

In this case, identified on the basis of the ambition self-evaluation degrees vary depending on whether the preschool teachers consider or do not consider themselves ambitious. The preschool teachers who consider themselves ambitious, note the medium and high degrees of ambition. The preschool teachers who consider themselves rather ambitious, note low, medium and high degrees (mainly high and medium). The preschool teachers who consider themselves rather unambitious noted the low and medium degrees of ambition. All preschool teachers who do not consider themselves ambitious, considered themselves as people with low degree of ambition or absolutely unambitious. The preschool teachers who found it difficult to evaluate themselves, note the medium degree of ambition.

Thus, most preschool teachers understand ambition as a motivational mental formation - the desire to make a career, get professional recognition and fame. Also, most preschool teachers consider themselves ambitious people and evaluate their ambition as medium (moderate) or high. The further study of the images and ambition self-evaluation through the expansion of the study sample, comparing ambition self-evaluation of the preschool teachers and representatives of other teaching professions - teachers, university professors, etc., seems promising.

\section{References}

1. Barsukova, O.V. (2010) Ambition: notion of ambition in literature, religion and philosophy. Monograph - St. Petersburg.: Speech. - 184 p.

2. Barsukova, O.V. (2011) Psychological structure of ambition / / The 12th European Congress of Psychology Istanbul July 04-08. Poster Abstracts. Page 664.

3. Barsukova, O.V. (2012a) Methodology of psychological study of ambition // Материали за 8-a международна научна практична конференция, «Ключови въпроси в съвременната наука», - 2012. Том 23. Политика. Психология и социология. София. «Бял ГРАД-БГ» ООД - 112 стр. С. 5153.

4. Barsukova, O.V., Viktorchik, I.S. (2012) Study of notions of ambition and ambition self-evaluation of students receiving continuing professional education // Materiály VIII mezinárodní vědecko - praktická conference «Vědecký pokrok na přelomu tysyachalety - 2012". - Díl 21. Psychologie a sociologie: Praha. Publishing House «Education and Science» sro - 72 stran. S. 11-15.

5. Panferov, V.N. (2009) Psychology of human relations. Selected works - St. Petersburg. ANO PPI 2009. - 497 pp. 